See discussions, stats, and author profiles for this publication at: https://www.researchgate.net/publication/291698522

\title{
Indigenous struggles within the colonial project: Reclaiming Indigenous Knowledges in the Western academy (2016)
}

Research · January 2016

DOI: $10.13140 /$ RG.2.1.3102.8247

CITATION

READS

1

386

2 authors, including:

Beth Leonard

Alaska Pacific University

24 PUBLICATIONS 91 CITATIONS

SEE PROFILE 
Leonard, B. \& Mercier, O. (forthcoming) Knowledge Cultures.

\title{
INDIGENOUS STRUGGLES WITHIN THE COLONIAL PROJECT: RECLAIMING INDIGENOUS KNOWLEDGES IN THE WESTERN ACADEMY
}

\author{
BETH R. LEONARD \\ brleonard@alaska.edu \\ University of Alaska Fairbanks \\ OCEAN R. MERCIER \\ Ocean.Mercier@vuw.ac.nz \\ Victoria University of Wellington
}

\begin{abstract}
In this article we investigate strategies for authentically engaging Indigenous knowledges in the epistemologically Western "uni-versity" using data from cross-institutional, virtual international student exchanges between University of Alaska Fairbanks and Victoria University of Wellington. Analysis of student perspectives on Indigenous Knowledges (IK) from discussion forums illustrates their growing understandings of IK as authentic, complex systems generating distinct theoretical and analytic frames providing innovative, cross-disciplinary processes and solutions to current challenges. Targeted and student-generated questions initiated dynamic dialogue, including: the intersections and divergences of Western and Indigenous knowledge systems; the roles of Indigenous languages in enhancing understandings of IK; the potential for bridging or interfacing IK and Western knowledge versus attempting to integrate those systems; and the future of IK in the academy in terms of Indigenous peoples' pursuit of self-determination and sovereignty.
\end{abstract}

Keywords: Indigenous studies, Indigenous knowledge, higher education

\section{Introduction}

Indigenous Knowledges (IK) have been a part of numerous academic places and spaces for millennia. Many of us, as Indigenous scholars, are situated within institutions located on Indigenous lands therefore in our minds IK occupies rightful places and spaces within these contexts. We are aware that Indigenous scholarship is underrepresented in many institutions that often teach about - rather than with and for Indigenous peoples. The authors of this paper hail from Indigenous/cross-cultural and Māori studies programs respectively, within institutions situated on Indigenous lands.

In 2007 we initiated a virtual, on-line exchange between University of Alaska Fairbanks (UAF) and Victoria University of Wellington (VUW) for students enrolled in graduate and undergraduate coursework focused on Indigenous knowledge, methodologies and science. We have since facilitated a total of five exchanges - with course foci that included cross-cultural communication and Indigenous science - using online discussion forums and videoconferencing (Leonard \& Mercier, 2014). In this article we examine strategies for authentically engaging IK in the Western academy through an analysis of a series of cross-institutional, international exchanges, with a focus on the most recent 8-week course "Indigenous Knowledge and Science." Since initiating these exchanges, "Indigenous struggles within the colonial project" has been a recurring course theme. As instructors we seek to clear a space for IK within the place of the Western institution, mindful that today's academy still resonates with the echoes of its genealogy of colonizing research. To reconfigure the culture in place requires an understanding of how 
that culture shapes that space, and potentially inflects any new spaces that might be envisaged and created. This leads us, both instructors and students, to use these exchanges to examine definitions, roles, research with, and ownership of IK in the academy, as a step toward clearing space within the "colonial project" and creating a place for Indigenous peoples and IK.

Our efforts in reclaiming and shaping Indigenous spaces in the academy honor and engage ongoing initiatives, strategies and models (Johnson, Archibald, Rigney \& Martin, 2014). In succeeding sections we provide a course overview and examine student commentary from course discussions. We discuss of the origins of Indigenous studies within UAF and VUW, including our institutions' stated responsibilities to Indigenous peoples. We conclude with observations regarding the "rightful home" of Indigenous studies in the academy.

\section{Indigenous knowledge[s] and science}

Mercier developed the special topic course "Science and Indigenous Knowledge" to enable students in Te Kawa a Māui School of Māori Studies to explore Māori connections with other Indigenous peoples. It flows on from a previous course focused on "Māori Science" exploring similar epistemological issues within a global context. Mercier gathered course curriculum material in 2006 and 2007 during her visit to UAF, and first offered the course "Science and Indigenous Knowledge" in 2007. In 2014 the course was renamed "Indigenous Knowledge(s) and Science in Global Contexts" and made a permanent course, contributing to the Māori Resource Management (MRM) major:

This course explores the interactions, historic and present, between Western science and Indigenous Knowledge, with a focus on mātauranga Māori [Māori knowledge]. By exploring recent initiatives to bridge the philosophical gap between Western science and Indigenous Knowledge, we will explore how these knowledge systems might work alongside each other. (Mercier, 2014, p. 2)

"Indigenous Knowledge(s) and Science" is recommended, not required for the MRM major, but attracts good numbers of students who are interested in Indigenous issues and have limited opportunities to learn about other Indigenous peoples and their knowledge systems. Most enrollees are Bachelor of Arts students majoring in Māori Studies, rather than MRM, although this is more a reflection on the small student numbers in the MRM programme. The course also attracts postgraduate diploma students and science majors, who have had the option since 2010 to cross-credit "Science and Indigenous Knowledge" and "Māori Science" towards their BSc study. This option is a significant advance in validating Māori and Indigenous Knowledges beyond social science spheres.

At UAF, "Indigenous Knowledge[s] and Science in Global Contexts" was developed in collaboration with Mercier as part of Leonard's 2014 Fulbright research and teaching scholarship. Represented in this graduate course are students from cross-cultural studies, education, restorative justice, and natural resources management. UAF's course description below is adapted from Mercier's syllabus (2009, pp. 1-2):

This course will provide students a critical framework for examining Science (as a Western or Indigenous construct) and Indigenous Knowledge[s] (IK or IKS) paradigms. As a holistic paradigm, it is difficult to compartmentalize and separate aspects of IK into Western academic categories. Students will explore the ideologies underlying Science and Indigenous Knowledge[s] including how aspects of each paradigm converge, diverge, or negotiate parallel paths. In addition, students will survey the methodologies of each, including how paradigms are constructed, deconstructed and reconstructed through the influence and engagement of Indigenous peoples. (Leonard, 2014, pp. 1-2) 


\section{Reclaiming Indigenous spaces in academic places}

As stated above, the co-authors of this paper work within institutions situated on Indigenous lands in Aotearoa and Alaska. Knowledge of the histories of these places and understanding how new spaces can be negotiated provides a gateway to authentically understanding both mātauranga Māori and Alaska Native knowledge systems. In the following sections we describe the origins and more recent recognition of these Indigenous places.

\section{Te Whare Wānanga o te Ūpoko o te Ika a Māui (www.victoria.ac.nz/about/victorias-} story/history/maori-name): Victoria University of Wellington began as a teaching facility in 1897 , and was named 'Victoria College' in recognition of the then Queen of England's diamond jubilee. Through the early 1900s buildings were progressively built on land in the suburb of Kelburn, overlooking the city of Wellington. Although there is no recorded evidence of tribal occupation of Kelburn, the area would have been well known by iwi (tribes) as a passage to different parts of the region: it was part of the hinterland for Te Aro, the site of a fortified village (pā); it is also en route to Mt. Ahumairangi, the west coast, and the forested valleys in between. The suburb of Karori, for instance, which until 2015 housed Victoria University's Education Faculty, was a well-known bird-hunting and snaring area, evident in its full name "Te Kaha o Ngā Rore" (the multitudes of bird snares). There remains physical evidence of coastal occupation beyond Karori, probably by the Ngāi Tara and/or Ngāti Ira tribes that had mana whenua (sovereignty) over the region prior to Te Atiawa/Taranaki Whānui. The latter migrated from the northwest coast to take occupation of coastal and valley regions of Wellington through force, in the early to mid-1800s. Ngāti Ira relocated to Wairarapa, northeast of Wellington.

After a period of consultation in the early 1990s with the Māori Language Commission and prominent Māori leaders and scholars, the university's Treaty of Waitangi Consultative Group suggested the Māori name 'Te Whare Wānanga o Te Ūpoko o te Ika a Māui' (the house of learning at the head of the fish of Māui), which was accepted by the Victoria University of Wellington Council in 1994. Incorporating the name 'te Ūpoko o te Ika a Māui', referring to the greater Wellington region, recalls Indigenous knowledge of the geological heritage of New Zealand's North Island. This is the oldest known name for the region, dating back to Kupe, who is acknowledged as the region's first Polynesian settler, in 1300 AD. Te Ika a Māui (Māui's fish) was hauled up out of the sea, and its topography hewn by the demigod Māui's brothers. The shape of the North Island outlined by its coast is like that of a stingray, with its head (ūpoko) at the southernmost end, and Wellington harbor defining its mouth. However, this alternate name for Victoria University of Wellington does little to raise general awareness of mātauranga Māori, and the creation of contemporary Indigenous place within the institution remains the task of staff and students.

Troth Yeddha': Archaeological evidence places Dena/Athabascan peoples in interior Alaska for approximately 12-15,000 years, although Elder commentary extends this period significantly. Preliminary recognition of "University Hill" as an Indigenous space came after a 1994 speech by the late Chief Peter John of Minto, Alaska. The former Director of Interior-Aleutians Campus created posters of John's speech, published in 1998. Inclusion of this information in the academic catalog followed seven years later in 2001 (www.uaf.edu/catalog/catalog_01-02/troth_yeddh.html) and finally in 2013-some 19 years later-the US Board of Geographic Names formally recognized Troth Yeddha' (www.uaf.edu/catalog/current/overview/troth_yeddha.html).

The late Traditional Chief Peter John of Tanana Chiefs Conference [a consortium of 42 Athabascan tribal governments] of interior Alaska said, "Our people used to come to this hill to pick Troth... Troth Yeddha' was important, a meeting place. The grandfathers used to come to talk and give advice to one another about what they were going to do. When they learned this place would be used for a school, the university, they came here one last time, to 
decide what they should do. They decided that the school would be good and would carry on a very similar traditional use of this hill-a place where good thinking and working together would happen... They were also giving a blessing to their grandchildren who would be part of the new school (http://archive.is/6gT0).

In describing the gifting of Troth Yeddha' to the then Territory of Alaska, the Tanana Dena claim an Indigenous pedagogy of place - a hope that "good thinking and working together" will continue; also that their grandchildren will be included and appropriately served by this new school. Chief John's words serve as an example of "learning relationships in context" as described by Tewa scholar Cajete (2000, $p$. 183): both the relationship of UAF to the land, or physical place, as well as the pedagogical place envisioned by the Tanana peoples (Leonard, 2013, p. 6). It is from this mindfulness that we reclaim space for Indigenous pedagogy in a contemporary setting, in order to shape Indigenous places at UAF.

\section{Ways of knowing and learning: science as a discourse}

Course readings were selected to encourage dialogue around knowledge systems - as a UAF student stated, "we need to get to a point where we can view all science as a discourse, not as objective truth" (I. Kemp, personal communication, 2 April 2014), illustrating an understanding of the political and social construction of knowledge in the academy. UAF students met in small groups prior to the videoconference exchange discussing questions around how knowledge systems are constructed and used, the perceived validity and status of "other" knowledge systems, and underlying ideologies of IK and science. Students explored foundational scholarship including Battiste \& Henderson (2000), Cajete (2000), Kawagley (2006) and Deloria, Jr. (2012, 1997). Shared readings between the two courses included "Disciplining the savages: Savaging the disciplines" (Nakata, 2007) and "Blackfoot Physics" (Peat, 2002).

Students regularly enter higher education with little understanding of how knowledge systems are constructed to serve various social agendas (Apple, 2014). Indigenous students may have varied knowledge of own heritages and cultures depending on where and how they were raised. Students frequently encounter disconnects in classroom education systems, and this may intensify at the university level if their "funds of knowledge" (González, Moll \& Amanti, 2005) are not engaged in respectful, authentic ways. The academy problematizes the study of IK through the disciplinary segregation of knowledge, resulting in the separation of "hard"/natural sciences and "soft"/social sciences. Indigenous studies coursework frequently harks back to anthropology, a social science-and is regularly confined to the soft science sphere as an-other body of knowledge subject to Western analytic frameworks. In terms of research methodology, IK's methods are often classified as empirical, lacking acknowledgement of the ways in which values and theory also inform these systems (Medin \& Bang, 2014).

At the undergraduate level, students are often expected to accept concepts and processes with few opportunities for question and critique. Additionally using Western disciplinary frames of analysis may cloud the authentic study of, and engagement with, IK. The following student's comment underscores the tension between the definitions of science versus definitions of Indigenous Knowledges in academic contexts: "it took me some time to figure out what science was in this class. It is pretty funny now. I finally realized that science is our traditional knowledge - a way of knowing and learning" (P. Hyslop, personal communication, 15 April 2014).

Early on in the course, an Alaska student and educator commented on status in classroom educational systems: "even though my school incorporates Indigenous Knowledge...it is still an ongoing challenge to battle the perception that the knowledge our Elders possess is 'real' science and not just stories" (S. Meierotto, personal communication, 31 March 2014). IK as systems of knowing, being, learning and doing engage oral traditions and stories as theory, and within applied realms. Oral traditions and story play significant roles in Western science, for example, through the exchange of ideas in conference or symposia venues and other contexts that inform written scholarly discourse-although this influence is rarely acknowledged. Bryan Brayboy (2005), a prominent Lumbee scholar, notes that 
"locating theory as something absent from stories and practices is problematic in many Indigenous communities and in the work of anthropologists who seek to represent Indigenous communities" (p. 426). Recognizing how the colonial project has defined research methodologies to the continued marginalization of Indigenous ontologies is an important step towards reclaiming space for Indigenous methods.

\section{Accidental drift? Unsettling definitions and histories}

Consider the arrival of the great fleet of canoe[s] to Aotearoa. The knowledge required to navigate such a large expanse of water was deemed impossible without modern tools like the sextant. For many years it was relegated to the theory of an accidental drift (A. Eparaima, personal communication, 15 April 2014).

In the academy, there is emerging validation of Indigenous cultures' expertise in the sciences - however dominant narratives persist in teaching and research agendas, and about expectations of the boundaries around Indigenous knowledge. As Métis scholar Chris Andersen (2009) observes, the "peculiar positioning of Indigenous studies as different needlessly marginalizes our density and, in doing so, unnecessarily gives ground to disciplinary turf long claimed by longer-standing disciplines" (p. 98).

Navigation, astronomy, agriculture, botany, democratic governance, and multiple other disciplines are credited to Western cultures, when in fact many Indigenous applications evolved earlier and in superior forms (Weatherford, 1988). After reading "Nature and Culture" (Forbes, 2001), a UAF student commented on how definitions have changed over time, for example the concept of nature that once included humans now separates humans from the rest of the natural world, with significant implications for science practices: "Forbes draws our attention to the concept of nature...our ignorance of the meaning of this concept and continued use of it perpetuates a dominant western epistemological discourse" (I. Kemp, personal communication, 31 March 2014).

Indigenous studies provides multiple and authentic counter-narratives that challenge dominant Euro-centric discourses. Early in our course we facilitated working definitions of knowledge systems and science in conjunction with an understanding of status issues around Alaska Native and Māori knowledges. This is clearly articulated in the following quote by a Māori studies student: "My argument... is that IK is civilised. IK is cultivated, it is refined, it is cultured, it is sophisticated; it is all of these and more" (A. Eparaima, personal communication, 7 April 2014). However, new forms of "settler colonialism" (Wolfe, 2006) are very much present in terms of who can access IK, for what purposes, and how control of knowledge is negotiated within the academy.

\section{Challenges and opportunities at the interface}

Conflict it would seem whether between Science and Indigenous Knowledge or personal relationships is an important part of evolution and an indicator of when we are at the interface (A. Mitchell, personal communication, 31 March 2014).

Discussions from 2014 and previous years examine ongoing struggles with the perceived validity of IK more broadly, its history and engagement in classroom education, and challenges in documentation and ownership of these systems. Students recognize that using Western disciplinary lenses fracture IK and otherwise provide barriers to authentic engagement of these systems.

Indigenous knowledge is tied to land, and many of our students took opportunities within the discussion forum to voice Indigenous knowledge in ways that personally connect them to their mountains, rivers, kin-animals and people: "we are lucky in Alaska, as we have not been moved from our traditional lands. They are the healers for us; the trees, trails, animals, birds and water" (P. Hyslop, personal communication, 31 March 2014). However, as Andersen (2009) points out, Indigenous studies is also 
concerned with understanding colonization, whiteness, privilege, epistemological systems and how these interact with, influence, and can continue to colonize Indigenous knowledge systems. Our students were also deeply cognizant of these issues, and reflected their experiences:

In Aotearoa we have kaupapa Maori schools which enable us to teach Science from an indigenous worldview. Mainstreams schools are attempting to include IK, but it is predominantly seen in the Arts classes such as drama, performing arts and some language classes. (A. Eparaima, personal communication, 21 April 2014)

Ramón Grosfoguel (2012) argues that in the Western academy epistemic racism and sexism are so hidden that moving to a state of recognition of these requires a complete overhaul of academia: "not a uni-versity (where one epistemology defines for the rest the questions and the answers to produce a colonial, universal social science and humanities) but a pluri-versity (where epistemic diversity is institutionally incorporated into necessary inter-epistemic dialogues in order to produce decolonial, pluriversal social sciences and humanities)" (p. 84). This uni-versal and fractured approach often prompted student commentary on a range of issues. For instance, the Western academy's tradition of validation through publishing is an approach that marginalizes Indigenous narratives. This marginalization can be experienced on a personal and emotional level, as illustrated in the quotes from two Aotearoa students: "is there a fear that the West will not take our history seriously unless it is recorded and reviewed by scholars?" (N. Turei, personal communication, 30 March 2014); and

While it is undeniable that GIS has benefits...there are still a series of concerns...including, once the information is stored in GIS who now has control... has the information...been correctly interpreted...does this lead to it [IK] becoming immobile or stagnant by not allowing it to evolve or change over time...? (E. Stevens, personal communication, 31 March 2014)

Terms such as 'fear', 'concerns' or 'stagnant' above signal that this interface is crucially relational, and requires the management of values, expectations and emotions. In fact it is less an intersectionality between disembodied 'neutral' knowledge systems and more like Nakata's 'cultural interface' (2002), where modes of interaction from both sides are socially bound and culturally inflected.

In addition, students were cognizant of issues of power and control over knowledges at the interface, whether the issue was one of seeing IK evolve in form or seeing them maintain their own identity: "a key question to address is how do we continue to move forward to not only find ways to combine both Western and Indigenous knowledge but also to honor the uniqueness of Indigenous ways of knowing?" (O. Skinner, personal communication, 31 March, 2014).

\section{Exploring the origins of IK in the academy}

In addressing the question of IK's "rightful place[s]" in the academy, it is useful to explore the origins of various programs teaching about, with, and/or for Indigenous peoples. As has been discussed at length, anthropology and social science methods, courses, programs and much scholarly literature continue to "other" Indigenous peoples and peoples of color. Alaska Natives pushed vigorously for authentic programs and coursework, prioritizing these initiatives during and after passage of the Alaska Native Claims Settlement Act (Jennings, 1994, p. 94). In 1970, responding to "academic interest in minority and ethnic groups" (Nanook News,1970, n.p.) a unit on Alaska Native history was included in the "Seminar in Northern Studies" and formal programming began that year under the first Alaska Native Studies director - Tlingit scholar Walter Sobeloff who directed the program until 1974 (Now in the North, 1979, p. 9). Another Tlingit scholar Dennis Demmert continued development of the program (Now in the North, 1979, p. 6), and in 1981 the Alaska Native Studies degree was established, under Director Michael Gaffney and housed in the College of Liberal Arts (Barnhardt, n.d.; UAF 1981-1983 Catalog, pp. 52-53). 
A broader focus on "Native Ways of Knowing"/IK began in the 1990s, fueled in part by the late Yup'ik scholar Oscar Kawagley, including publication of "A Yupiaq worldview: A pathway to ecology and spirit" (1999). Evolving from a number of earlier projects by Indigenous scholars/educators, and heavily influenced by Kawagley's dissertation (1993), the Alaska Rural Systemic Initiative (AKRSI) began in 1995, funded by the National Science and Annenberg foundations. This initiative was designed to integrate Alaska Native Knowledge into classroom content with an overarching goal of improving student achievement in Alaska's pre-college classroom systems (Barnhardt, 2012).

The Alaska Native Knowledge Network, created during AKRSI, is a nationally and internationally recognized database of Indigenous curriculum resources housed at UAF. Also noteworthy in 1995 was the pilot videoconference course, "Native Ways of Knowing" taught by Kawagley and housed in both the education and Alaska Native studies programs. "Native Ways of Knowing" engaged multiple University of Alaska sites and was televised throughout Alaska. Kawagley's approach allowed an open space for the exploration of how Alaska Native values, oral traditions, pedagogy, subsistence practices and other cultural aspects generate Alaska Natives' unique systems of knowing being and doing; including how these systems were often traumatically impacted by Western education, disease, displacement, forced removal, and other events (Napoleon, 1996). Barnhardt and Kawagley served as faculty in the UAF School of Education, prior to moving the Center for Cross-Cultural Studies (CCS) into the College of Liberal Arts, and shifting their focus to graduate programming.

In 2002 "Indigenous Knowledge Systems" and "Documenting Indigenous Knowledge" became core courses in the CCS MA program and now serve graduate students in education, rural development, northern studies, anthropology, natural resources management, psychology and interdisciplinary studies. Kawagley's and Barnhardt's work continues to impact students beyond the CCS and education programs, demonstrating an expansion of places and spaces for IK in the academy. The College of Rural and Community Development now houses the Alaska Native Studies and Rural Development programs. Additional coursework offered through these programs (regularly taught by Indigenous scholars) includes "Cultural Knowledge of Alaska Native Elders," "Native Ways of Knowing" and "Native Ways of Healing."

At Victoria University of Wellington, a notional Department of Anthropology appointed Joan Metge (Te Kawa a Māui, 2015) in 1965 as a senior lecturer with special reference to Māori studies, and simultaneously seconded Māori teacher Wiremu (Bill) Parker to teach te reo Māori; however Parker was terminated when university discovered he was not "degreed." Te Kawa a Māui notes that the "University's insistence on its own benchmarks of academic excellence, at a time when there were few Māori graduates, seemed ill-judged and unfortunate" $(2015$, p. 9). Parker would later be instrumental in the establishment of the country's first university-based marae, at VUW. In 1966, Te Kapunga (Koro) Dewes, a graduate of the University of Auckland, was appointed to the Lectureship in Māori Studies. Within the Department of Anthropology leadership of Māori Studies passed to Dr. Hirini Moko Mead in 1975, and in 1978 Māori Studies became a stand-alone department. In 1980, Te Herenga Waka marae was established on the campus, under the leadership of Mead, Parker and Ruka Te Rangiahuta Broughton (Te Kawa a Māui, 2015).

Te Tumu Herenga Waka, the carved meeting house on the marae complex, behind the Māori Studies offices, hosts meetings with visitors from all over Aotearoa New Zealand and the world, observing traditional Māori protocols (including the use of only Indigenous languages during the pōwhiri, or formal welcoming ceremony) and providing a whare whakaruruhau (safe space for learning, communicating, performing and sleeping) for students. Mead's effort to establish it on campus was motivated by his belief in the need "to provide a distinctly Māori space that Māori students at Victoria could feel comfortable in as well as providing a culturally appropriate teaching space that could be used for the tuition of mātauranga Māori using Māori pedagogies” (Te Kawa a Māui, 2015, p. 11).

Te Kawa a Māui School of Māori Studies also hosted Cook Island Studies and Samoan Studies through the late 1980s, and Pacific Studies in 2000, before the academics of these specializations established their own school, Va'aomanu Pasifika, in 2005. Today, Te Kawa a Māui offers undergraduate 
degree programmes over three majors: Māori language, Māori studies and Māori resource management, as well as hosting eight permanent academic staff. As of 2015, all faculty are now able to supervise students through to Masters and $\mathrm{PhD}$ level, a significant shift from the situation when Mercier first joined the department in 2004, when she was the only one out of six staff qualified (in Western academic terms) to supervise $\mathrm{PhD}$ students.

\section{Indigenous knowledges in higher education: political acts of decolonization}

Paul Boyer (2010) discusses the significance of including IK in tribally-controlled colleges:

I believe we are performing acts of decolonization by giving our students access to their tribal knowledge. We are adding experiences and knowledge back rather than taking something away from our students or leaving them with a vacant space. We are helping students relearn their personal and community history. We are helping them regain their connections to the land. (pp. 27-28)

Neither UAF nor VUW are classified as tribal colleges as such, however, each institution enrols a significant percentage of Indigenous students, and both universities have publicly stated responsibilities to Indigenous students and communities. Core themes within UAF's strategic plan include a commitment to "incorporate traditional and local knowledge more fully in appropriate curricula at every level from college preparation to graduate programs" (p. 3) and "double the number of Alaska Native graduate students" (p. 5, www.uaf.edu/files/provost/assessment-review/program-review/MissionCoreThemes.pdf). UAF's academic plan highlights the institution's pledge to provide "service to rural and Alaska Native peoples... as central to the strategic direction of UAF" (p. 1); as well as fostering "the success of Alaska Native students and research concerning Alaska Native peoples, including documentation and preservation of languages and culture" (p. 2, www.uaf.edu/provost/general-information-1/academic-plan).

"Shaping Alaska's Future" (SAF, www.alaska.edu/files/shapingalaskasfuture/SAF-FINAL.pdf) was published in 2014 as a strategic directions initiative, designed to shape policy at each of the major administrative units and their affiliated rural campuses. Key statements referencing Alaska Native peoples, cultures, languages and knowledge include:

- UA recruitment, retention and graduation rates are low, especially for disadvantaged and minority populations and for Alaska Natives. Effect: UA graduates reflect the diversity of Alaska (p. 7).

- Some Alaska Native languages and cultural traditions are endangered. Many communities do not have sufficient resources to safeguard and nurture culture and the arts, so UA plays a vital role in preserving and advancing this knowledge and these traditions. Effect: UA is a major center of culture and the arts in Alaska and is a center of excellence for Alaska Native and indigenous research and scholarship (p. 13).

- Circumpolar communities are experiencing rapid social and economic transformation...These communities need research-based and indigenous knowledge in order to adapt. UA has the expertise to assist these communities, and to do so must effectively communicate with those who need it...Effect: Alaskans and their communities use research-based information, enriched by traditional knowledge, to successfully adapt to change (p. 13).

There are a number of problematic orientations in the SAF document: these include deficit assumptions regarding Alaska Native people's abilities to maintain their cultures and languages, and the overtly hierarchical separation of "research-based [knowledge]" and "Indigenous knowledge." In any case, fulfilling these commitments to Alaska Native peoples continues to be a decolonization challenge in the absence of adequate numbers of Indigenous faculty who can shape recruitment, teaching, research, and service policies, with and for Alaska Native communities. The University of Alaska Fairbanks has a significant number of Alaska Native students-18.5\% as of Fall 2014-however, Indigenous faculty have never exceeded $5 \%$ of total faculty. And these percentages are ambiguous since there are several different 
categories of faculty at UAF, including permanent (tenured) faculty, those eligible for a permanent position (tenure-track) and those under term/temporary contracts.

At VUW, the Treaty of Waitangi Statute formally expresses a commitment to Māori as tangata whenua and Treaty partners. This reflects the embedding of the Treaty principle of partnership in most major organizations in Aotearoa New Zealand.

Victoria is committed to: Māori student recruitment, retention, and achievement: Maori research excellence with the potential for significant social, economic and scholarly impacts; the contribution of Mātauranga Māori (Māori knowledge) to scholarship across the disciplines; building long-term and positive relationships with Māori stakeholders; building Māori staff capability; increasing the capability of all staff to engage with Māori interests; the contribution of Te Reo Māori and Tikanga Māori to the cultural life of Victoria. (www.victoria.ac.nz/maori-at-victoria/rangatiratanga/waitangi)

Also reflected in VUW's 2014 Strategic Plan are seven primary strategies that will enable the university to "adopt a distinctive academic emphasis, underpinned by excellence and with a particular focus on advancing Wellington, New Zealand and the Asia-Pacific region. Victoria will be imbued with distinctive qualities through its values and through the Treaty of Waitangi, mātauranga Māori and te reo Māori" (Victoria University of Wellington, 2014, p.7):

Primary Strategy 4-Secure the intellectual potential put at risk through experience of disadvantage. Victoria University will endeavour to increase enrolments of talented students currently denied access to university study by their social, cultural or financial circumstances or by disabilities. Victoria will enrol 1,000 Māori students over and above the current number and reach a similarly increased proportion of Pasifika students. The progression of students from under-represented groups to postgraduate study is vital if the University, and New Zealand more generally, are to have the opportunity to employ additional talented and qualified staff representing the diversity of New Zealand society.

This strategic plan couches the usual deficit discourse in terms of its responsibilities to the wider Māori and Pasifika community. While the University's assumption, as Primary Strategy 4 goes on to state, of the responsibility to rescue 'intellectual potential' could be seen as somewhat patronizing, its nonetheless bold commitment to lift the numbers of Māori (and by implication, Pasifika) students by nearly 50\% of the current enrolments, provides Māori and Pasifika staff with powerful leverage for our own recruitment efforts.

Victoria will maximise its efforts to recruit such students and retain them through to successful Master's and doctoral degrees. In addition, the University will do all it can to help the nation to secure the intellectual potential of these 'missing thousands' through collaboration with schools and communities, through the focus and quality of its teacher education programmes and through the outcomes of each of the distinctive academic themes identified on page 13. (Victoria University of Wellington, 2014, p. 19)

Working against those efforts are similar issues to those experienced at UAF. While the percentage of Māori students is commensurate with their population in the region (just over 10\%), the proportion of full-time Māori academic staff is less than 2\%. As noted elsewhere (Mercier et. al., 2011), academics are motivated to "go the extra mile" to realize emancipatory outcomes for their students, but are stretched beyond their job descriptions, and well beyond in comparison to expectations of non-Māori academics. In addition, the recently vacated position of Māori recruitment officer was re-advertised. As a general staff member noted in an email response to this advertisement, given the university's push to recruit 1000 more Māori students, it would make sense to increase the number of recruitment staff. This was clearly a missed opportunity on behalf of the university to give immediate effect to one of its primary strategies.

The strategic plan, in the 'Values and commitments' section, goes on to state: 
With, and as, tangata whenua, we value te Tiriti o Waitangi, rangatiratanga (leadership), manaakitanga (the generous fostering of knowledge), kaitiakitanga (responsibility for, and guardianship of, knowledge), whai mātauranga (intellectual curiosity), whanaungatanga (collaboration and collectiveness) and akoranga (collective responsibility for learning).

(Victoria University of Wellington, 2014, p. 11)

Challenges of increasing Māori student numbers with the same resources notwithstanding, statements such as the above help to normalize Indigenous discourse and pedagogy in the academy; contributing also to the reclaiming of Indigenous practices.

\section{Reclaiming IK in the academy: concluding comments}

In this article we have provided an overview of our virtual exchange coursework, highlighting student comments from 2014. We have also explored past and present IK in our academies, including places where IK continues to survive and thrive, and spaces that can be shaped into contemporary Indigenous place. The future of IK in the academy is contingent on many complex factors including executive level leadership and programmatic commitment, with recognition of-and strategies to address-the sacred, "non-public" aspects of IK. Indigenous, Alaska Native, and Māori studies programs have already assisted in the reform and improvement of the academy for the benefit of all students. If institutions are to meet their goals in terms of Indigenous recruitment, retention and improved graduation rates, additional reforms and adaptations in program philosophies and pedagogies, as well as power sharing in collaborative ventures will be necessary.

As to the "rightful home" of IK in the Western academy, we provide the following observations:

1. The entire academy is potentially a space for reclamation: our point that universities were built on Indigenous lands reminds us of that spatial continuity;

2. In spite of uni-versal epistemological tendencies, the academy has (albeit sometimes begrudgingly) allowed Indigenous peoples to carve out space, and considering current strategic planning statements, the university appears to be moving to a stated position of active support for increasing numbers of Indigenous students, and inclusion of Indigenous content and teaching;

3. Kaitiaki/Indigenous stewards must continue to occupy and claim space in the academy, and to inform and decide upon how initiatives such as "1000 more Māori students" can be achieved in practice;

4. Historically it is Indigenous studies units that have allowed the fullest and freest expressions of Indigenous knowledge.

Finally, perhaps it is the overtly uni-versity-ness of our institutions that has caused us to collaborate in this way. We recognize the unique local contexts of Indigenous groups, while gaining solidarity with each other through shared colonial experiences, as do our students. Perhaps it is only through these kinds of lateral collaborations across cultures and nations that the university will be able to open itself up to the possibilities of multiple intersectionalities and the un-settling of dominant Western paradigms.

\section{Acknowledgements}

We are grateful to our students for their enthusiastic contributions to the UAF-VUW exchange. This work was partially funded by Ngā Pae o te Māramatanga under CAG-15KT27 and Leonard's 2014 Fulbright New Zealand U.S. Core Teaching/Research Scholarship. 


\section{REFERENCES}

Apple, M. (2014). Official knowledge: Democratic education in a conservative age. NY: Routledge. Andersen, C. (2009). Indigenous Studies: From difference to density. Cultural Studies Review. 15(2), $97-$ 116.

Barnhardt, R. (2012). Indigenous education renewal in Alaska. NABE Perspectives, (July-August). Retrieved from http://www2.nau.edu/ jar/NABE/BarnhardtCol.pdf

Barnhardt, R. (n.d.). Rural education development in Alaska: 1970-1988. Unpublished timeline.

Battiste, M. \& Henderson, S. Y. (2000). Protecting indigenous knowledge and heritage: A global challenge. Saskatoon: Purich Pub.

Boyer, P. (Ed.). (2010). Ancient wisdom, modern science: The integration of Native knowledge in math and science at tribally controlled colleges and universities. Pablo, MT: Salish Kootenai College Press.

Brayboy, B. (2005). Toward a tribal critical race theory in education. The Urban Review. 37(5), 425-446.

Cajete, G. (2000). Indigenous knowledge: The Pueblo metaphor of Indigenous education. In M. Battiste (Ed.), Reclaiming Indigenous voice and vision (pp. 181-191). Vancouver: UBC Press.

Deloria, Jr., V. (1997). Red earth white lies: Native Americans and the myth of scientific fact. Colorado: Fulcrum Publishing.

Deloria Jr., V. (2012). The metaphysics of modern existence. Golden, CO: Fulcrum Publishing.

Dennis Demmert appointed staff assistant to president. (1979, February). Now in the North: A University of Alaska Report 9(1), 7.

Forbes, J. D. (2001). Nature and culture: Problematic concepts for Native Americans. In J. A. Grim (Ed.), Intellectual property rights and the sacred balance: Some spiritual consequences from the commercialization of traditional resources (pp. 103-124). Cambridge: Harvard University Press.

González, N., Moll, L., \& Amanti, C. (2005). Funds of knowledge: Theorizing practices in households, communities and classrooms. Mahwah, NJ: Lawrence Erlbaum Associates.

Grosfoguel, R. (2012). The dilemmas of ethnic studies in the United States: Between liberal multiculturalism, identity politics, disciplinary colonization, and decolonial epistemologies. Human Architecture: Journal of the Sociology of Self-Knowledge. 10(1), 81-89.

Jennings, M. (1994). One university, two universes: The emergence of Alaska Native political leadership and the provison of higher education, 1972-85 (unpublished doctoral dissertation). University of British Columbia, Vancouver.

Johnson, S., Archibald, J., Rigney, L. \& Martin, G. (2014). Editorial: Indigenizing the international academy. Canadian Journal of Native Education, 37(1), 1-8.

Kawagley, A. O. (1993). A Yupiaq world view: Implications for cultural, educational, and technological adaptation in a contemporary world (unpublished doctoral dissertation). University of British Columbia, Vancouver.

Kawagley, A. O. (1999). A Yupiaq worldview: A pathway to ecology and spirit (1 $1^{\text {st }}$ ed.). Long Grove, IL: Waveland Press, Inc.

Kawagley, A. O. (2006). A Yupiaq worldview: A pathway to ecology and spirit (2 ${ }^{\text {nd }}$ ed.). Long Grove, IL: Waveland Press, Inc.

Leonard, B. (2013). Indigenous pedagogies in the oral traditions of Belle Deacon. Journal of American Indian Education, 52(3), 3-20.

Leonard, B. (2014). Indigenous Knowledge and Science in Global Contexts [Syllabus]. Fairbanks, AK: Center for Cross-Cultural Studies, University of Alaska Fairbanks.

Leonard, B., \& Mercier, O. (2014). Shaping Indigenous spaces in higher education: An international virtual exchange on Indigenous knowledge. Canadian Journal of Native Education, 37(1), 218 238.

Medin, D. L., \& Bang, M. (2014). Who's asking?: Native science, Western science, and science education. Massachusetts: MIT Press. 
Mercier, O. (2009). Special Topic: Science and Indigenous Knowledge [Course Outline]. Wellington, NZ: Te Kawa a Māui, Victoria University of Wellington.

Mercier, O., Asmar, C., \& Page, S. (2011). An academic occupation: Mobilisation, sit-in, speaking out and confrontation in the experiences of Māori academics. Australian Journal of Indigenous Education, 40(11), 81-91.

Nakata, M. (2002). Indigenous Knowledge and the cultural interface: Underlying issues at the intersection of knowledge systems. IFLA Journal. 28(5,6), 281-291

Nakata, M. (2007). Disciplining the savages: Savaging the disciplines. Canberra, Australia: Aboriginal Studies Press.

Napoleon, H. (1996). Yuuyaraq: The way of the human being. Fairbanks: University of Alaska Press.

Peat, F. D. (2002). Blackfoot physics: A journey into the Native American universe. Grand Rapids, MI: Phanes Press.

Te Kawa a Māui (2015). Academic Programme Review: Te Kawa a Māui, School of Māori Studies. SelfReview Document 2015. Unpublished Report. Wellington: Victoria University of Wellington.

University of Alaska. (2014). Shaping Alaska's Future. Unpublished Report. Fairbanks: University of Alaska Office of Academic Affairs and Public Affairs. Available https://www.alaska.edu/files/shapingalaskasfuture/SAF-FINAL.pdf

University of Alaska Fairbanks (2014). UAF Strategic Plan 2012-2019. Unpublished Report. Fairbanks, University Alaska Fairbanks. Available http://www.uaf.edu/files/provost/UAF-Strategic-Plan2012-19.pdf

University of Alaska Fairbanks (1980). 1981-1983 catalog. Fairbanks: University of Alaska.

University offers new courses in several ethnic cultures. (1970, September 20). Nanook news: Special new faculty issue. 14, n.p.

Victoria University of Wellington (2014). Victoria University of Wellington Strategic Plan. Wellington: Victoria University of Wellington. Available http://www.victoria.ac.nz/documents/policy/strategies/strategic-plan.pdf Accessed 15 December 2015

Weatherford, J. (1988). Indian givers: How the Indians of the Americas transformed the world. New York: Ballantine Books.

Wolfe, P. (2006). Settler colonialism and the elimination of the native. Journal of Genocide Research 8(4), 387-409. 